\title{
Hubungan Current Ratio, Struktur Modal, dan Ukuran Perusahaan terhadap Kinerja Keuangan Perusahaan Pertambangan yang Terdaftar di BEI Periode 2014-2016
}

\section{Hartoyo}

Akuntansi, Politeknik Pratama Mulya Surakarta, Indonesia

Korespondensi penulis: se_hartoyo@yahoo.com

\begin{abstract}
This study aims to find out and to analyze the Current Ratio, Capital Structure, and Corporate Size partially affect the Financial Performance of Mining Companies listed on the Indonesian Stock Exchange (BEI) in the period 2014-2016. The sample used is 120 financial statements of mining companies listed in BEI. The method used in sampling is purposive sampling. Data is collected by downloading, recording, researching, and copying information relating to the issues discussed in the study. Data analysis using descriptive statistics, classical assumption test, and multiple linear regression analysis, $t$-test, and coefficient of determination $\left(R^{2}\right)$. The results of this study indicate that current ratio and the size of the company does not affect on financial performance of mining companies on BEI in the 2014-2016, while the capital structure has a significant effect on the financial performance of mining companies on the company's financial performance.
\end{abstract}

Keywords: Current ratio, Capital structure, Company size, Financial performance.

\begin{abstract}
Abstrak: Penelitian ini bertujuan untuk mengetahui dan menganalisis Current Ratio, Struktur Modal, dan Ukuran Perusahaan secara parsial mempengaruhi Kinerja Keuangan perusahaan pertambangan yang terdaftar di Bursa Efek Indonesia (BEI) pada periode 2014-2016. Sampel yang digunakan adalah 120 laporan keuangan perusahaan pertambangan yang terdaftar di BEI. Metode yang digunakan dalam pengambilan sampel adalah purposive sampling. Data dikumpulkan dengan mengunduh, merekam, meneliti, dan menyalin informasi yang berkaitan dengan masalah yang dibahas dalam penelitian ini. Analisis data menggunakan statistik diskriptif, uji asumsi klasik, dan analisis regresi linier berganda, $t$-test, dan koefisien determinasi $\left(\mathrm{R}^{2}\right)$. Hasil penelitian ini menunjukkan bahwa current ratio dan ukuran perusahaan tidak berpengaruh terhadap kinerja keuangan pada perusahaan pertambangan di BEI pada periode tahun 2014-2016, sedangkan struktur modal berpengaruh signifikan terhadap kinerja keuangan perusahaan tersebut.
\end{abstract}




\section{LATAR BELAKANG}

Perusahaan selalu dituntut untuk meningkatkan kinerjanya. Kinerja yang dimaksud adalah kinerja keuangan perusahaan yang akan dinilai oleh investor. Dalam pengukuran kinerja keuangan perusahaan dapat menggunakan dua macam pengukuran, yaitu pengukuran berdasarkan pasar dan akuntansi (Al-Tuwaijri dkk., 2004). Pengukuran berdasarkan akuntansi hanya fokus pada kondisi finansial perusahaan, yaitu reaksi pendapatan pada perubahan kebijakan akuntansi.

Pada umumnya, pengukuran berdasarkan akuntansi menggunakan rasio profitabilitas yang hanya menggunakan pengukuran berdasarkan laba. Rasio profitabilitas dapat diukur dengan menggunakan ROA (Return on Assets) dan ROE (Return on Equity). ROA fokus pada kemampuan perusahaan untuk memperoleh laba dalam aktifitas perusahaan, tetapi ROE hanya mengukur tingkat pengembalian yang diperoleh dari modal yang ditanamkan pemilik pada perusahaan tersebut. Penelitian ini lebih berfokus pada penggunaan return saham, karena dirasa lebih objektif dibandingkan dengan laba yang dihasilkan oleh perusahaan. Prinsip memaksimalkan laba banyak dilanggar perusahaan, seperti penggunaan teknologi dan zat kimia berbahaya secara tidak bertanggung jawab dalam kegiatan perusahaan yang akan berdampak pada permasalahan lingkungan hidup (Angela \& Yudianti, 2015).

Indonesia merupakan salah satu negara yang kaya akan sumber daya alam, baik sumber daya yang tidak dapat diperbarui maupun yang dapat diperbarui. Sumber daya alam yang tidak dapat diperbarui di Indonesia, salah satunya adalah sektor pertambangan. Mayoritas produksi pertambangan di Indonesia terdiri atas batu bara, timah, tembaga, emas, dan amonia. Pertumbuhan di sektor pertambangan untuk periode tahun 2013-2016 diprediksi sekitar 8,27\% (Werner, 2013). Indonesia juga dikenal sebagai negara pengekspor batu bara keempat terbesar di dunia pada World Coal Statistics (WCS) pada tahun 2012 dan berhasil mengekspor sebanyak 443 juta ton batu bara. Prestasi Indonesia dalam Top Ten Coal Producers tahun 2012 berada pada posisi keempat (Yanti \& Budiasih, 2016).

Laba perusahaan dapat diukur melalui ROE perusahaan. ROE digunakan untuk mengukur efektifitas perusahaan dalam menghasilkan keuntungan dengan memanfaatkan ekuitas yang dimilikinya. ROE merupakan rasio antara laba setelah pajak (EAT atau earning after tax) dengan total ekuitas. Alat ukur kinerja suatu perusahaan yang paling popular antara penanam modal dan manajer senior adalah hasil atas hak pemegang saham, yaitu return on equity (ROE). Semakin tinggi laba perusahaan, maka akan semakin tinggi ROE, sedangkan besarnya laba perusahaan juga dipengaruhi oleh beberapa faktor seperti CR (current ratio) dan DER (debt to equity ratio).

Berdasarkan data statistik Bank Indonesia, aliran investasi langsung di Indonesia menurut sektor ekonomi pada tahun 2010-2014 mengalami peningkatan pada sektor pertanian dan pertambangan. Berdasarkan data statistik tersebut, posisi investasi internasional Indonesia pun mengalami peningkatan pada tahun 2010-2013. Hal ini menunjukkan besarnya dana yang tersedia untuk modal. Seharusnya, sektor utama mempunyai pendanaan yang memadai dengan potensi melimpahnya sumber daya alam yang dimiliki Indonesia. Tetapi kenyataannya, kinerja keuangan perusahaan sektor utama mengalami penurunan dilihat dari berkurangnya jumlah perusahaan sektor utama yang tercatat dalam indeks LQ45. 
Ukuran perusahaan merupakan suatu skala yang berfungsi untuk mengklasifikasikan besar kecilnya suatu entitas. Secara umum, perusahaan besar akan mengungkapkan informasi sosial atau tanggung jawab sosial lebih banyak daripada perusahaan kecil. Hal ini dapat dijelaskan secara teoritis bahwa perusahaan besar merupakan entitas bisnis yang tidak lepas dari risiko tekanan politis yang lebih besar dibandingkan perusahaan kecil (Maiyarni dkk., 2014). Dari uraian tersebut, tujuan penelitian ini adalah membuktikan dan menganalisis current ratio, struktur modal, dan ukuran perusahaan yang secara parsial berpengaruh terhadap kinerja keuangan perusahaan pertambangan yang terdaftar di BEI (Bursa Efek Indonesia) pada periode tahun 2014-2016.

\section{KAJIAN TEORITIS}

Bagian ini akan menguraikan teori-teori yang berkaitan dengan kinerja lingkungan dan kinerja keuangan perusahaan. Kajian teoritis ini akan digunakan sebagai dasar mengembangkan rerangka konseptual dan hipotesis.

\section{Teori Legitimasi}

Menurut Hadi (2011:87), legitimasi organisasi dapat dilihat sebagai sesuatu yang diberikan masyarakat kepada perusahaan dan sesuatu yang diinginkan atau dicari perusahaan dari masyarakat. Dengan demikian, legitimasi merupakan manfaat atau sumber daya potensial bagi perusahaan untuk bertahan hidup (going concern). Sejalan dengan karakternya yang berdekatan dengan ruang dan waktu, legitimasi mengalami pergeseran bersamaan dengan perubahan dan perkembangan lingkungan dan masyarakat di mana perusahaan berada. Perubahan nilai dan norma sosial dalam masyarakat sebagai konsekuensi perkembangan peradaban manusia juga menjadi motivator perubahan legitimasi perusahaan di samping juga dapat menjadi tekanan bagi legitimasi perusahaan (Lindblom, 1994 dalam Hadi, 2011:88).

Berdasarkan Standar Akuntansi Keuangan (SAK) tentang legitimasi Penyajian Laporan Keuangan menyebutkan: "Beberapa entitas juga menyajikan, dari laporan keuangan, laporan mengenai lingkungan hidup, dan laporan nilai tambah, khususnya bagi industri di mana faktor lingkungan hidup adalah signifikan dan ketika karyawan diangggap sebagai kelompok pengguna keuangan yang memegang peranan penting. Laporan yang disajikan di luar laporan keuangan tersebut adalah di luar ruang lingkup $S A K$." Hal ini memiliki makna lain bahwa laporan yang berkaitan dengan lingkungan hidup dapat disajikan secara terpisah dari laporan keuangan dan pengungkapan lingkungan merupakan salah satu legitimasi.

\section{Teori Stakeholder}

Stakeholder merupakan individu, sekelompok manusia, komunitas atau masyarakat, baik secara keseluruhan maupun secara parsial yang memiliki hubungan, serta kepentingan terhadap perusahaan. Individu, kelompok, maupun masyarakat dapat dikatakan sebagai stakeholder jika memiliki kekuasaan, legitimasi, dan kepentingan terhadap perusahaan (Budimanta dkk., 2008). Konsep yang mendasari mengenai siapa saja termasuk dalam stakeholder perusahaan, sekarang ini telah berkembang mengikuti perubahan lingkungan bisnis dan kompleksnya aktivitas bisnis perusahaan. 


\section{Kinerja Keuangan Perusahaan}

Pengertian kinerja menurut Bastian (2006:274) adalah gambaran pencapaian pelaksanaan/program/kebijakan dalam mewujudkan sasaran, tujuan, misi, dan visi suatu organisasi. Konsep kinerja keuangan menurut Gitosudarmo dan Basri (2002:275) adalah rangkaian aktivitas keuangan pada suatu periode tertentu yang dilaporkan dalam laporan keuangan, di antaranya laporan laba rugi dan neraca. Kinerja perusahaan merupakan suatu gambaran tentang kondisi keuangan perusahaan yang dianalisis dengan alat-alat analisis keuangan, sehingga dapat diketahui mengenai baik buruknya keadaan keuangan perusahaan yang mencerminkan prestasi kerja dalam periode tertentu. Hal ini sangat penting agar sumber daya digunakan secara optimal dalam menghadapi perubahan lingkungan.

Menurut Fahmi (2011:2), kinerja keuangan adalah suatu analisis yang dilakukan untuk melihat sejauh mana suatu perusahaan telah melaksanakan dengan menggunakan aturan-aturan pelaksanaan keuangan secara baik dan benar. Kinerja perusahaan merupakan suatu gambaran tentang kondisi keuangan perusahaan yang dianalisis dengan alat-alat analisis keuangan, sehingga dapat diketahui mengenai baik buruknya keadaan keuangan perusahaan tersebut yang mencerminkan prestasi kerja dalam periode tertentu. Penilaian kinerja keuangan merupakan salah satu cara yang dapat dilakukan oleh pihak manajemen agar dapat memenuhi kewajibannya terhadap para penyandang dana dan untuk mencapai tujuan yang telah ditetapkan oleh perusahaan.

\section{Current Ratio}

Menurut Kasmir (2014:134), rasio lancar (current ratio) merupakan rasio untuk mengukur kemampuan perusahaan membayar kewajiban jangka pendek atau utang yang segera jatuh tempo pada saat ditagih secara keseluruhan. Dengan kata lain, seberapa besar aktiva lancer yang tersedia untuk menutupi kewajiban jangka pendek yang segera jatuh tempo. Rasio lancar dapat pula dikatakan sebagai bentuk untuk mengukur tingkat keamanan (margin of safety) suatu perusahaan.

Bagi pihak di luar perusahaan, seperti pihak penyandang dana (kreditor), investor, distributor, dan masyarakat luas, rasio likuiditas bermanfaat untuk menilai kemampuan perusahaan dalam membayar kewajiban kepada pihak ketiga. Munawir (2007:72) menyatakan bahwa rasio yang paling umum digunakan untuk menganalisis posisi modal kerja suatu perusahaan adalah current ratio, yaitu perbandingan antara jumlah aktiva lancar dengan hutang lancar. Rasio ini menunjukkan bahwa nilai kekayaan lancar (yang segera dapat dijadikan uang) ada sekian kalinya hutang jangka pendek. Berdasarkan beberapa definisi di atas, dapat disimpulkan bahwa current ratio merupakan rasio untuk mengukur likuiditas perusahaan dalam membayar hutang jangka pendek dengan aset lancar yang dimiliki perusahaan.

\section{Struktur Modal}

Struktur modal merupakan bauran pendanaan hutang jangka panjang dan ekuitas (Brealey et al., 2011:600). Struktur modal merupakan cara perusahaan untuk membentuk sisi kanan neraca yang terdiri atas modal dan hutang (Zani et al., 2013). Struktur modal terdiri atas pendanaan jangka pendek, pendanaan jangka panjang, dan ekuitas. Hutang 
jangka pendek dan jangka panjang dapat diperoleh dari pihak eksternal perusahaan. Hutang jangka panjang akan digunakan oleh perusahaan untuk membiayai investasi modal. Hutang hipotik dan obligasi merupakan contoh hutang jangka panjang. Hutang hipotik dapat disebut juga secured debt. Debt to Equity Ratio (DER) adalah rasio yang digunakan untuk mengukur penggunaan hutang terhadap total shareholder's equity yang dimiliki perusahaan. Rumusan untuk mencari DER dapat digunakan perbandingan antara total utang dengan total ekuitas sebagai berikut (Wild, 2005:41).

\section{Ukuran Perusahaan}

Menurut Sartono (2010:249), perusahaan besar yang sudah well-established akan lebih mudah memperoleh modal di pasar modal dibanding dengan perusahaan kecil. Karena kemudahan akses tersebut berarti perusahaan besar memiliki fleksibilitas yang lebih besar pula. Menurut Fahmi (2011:2), semakin baik kualitas laporan keuangan yang disajikan, maka akan semakin menyakinkan pihak eksternal dalam melihat kinerja keuangan perusahaan tersebut, yang otomatis tentunya pihak-pihak yang berhubungan dengan perusahaan akan merasa puas dalam berbagai urusan dengan perusahaan.

Menurut Niresh (2014:57), ukuran perusahaan adalah faktor utama untuk menentukan profitabilitas dari suatu perusahaan dengan konsep 8/11 yang biasa dikenal dengan skala ekonomi. Maksudnya, skala ekonomi menunjuk kepada keuntungan biaya rendah yang didapat oleh perusahaan besar karena dapat menghasilkan produk dengan harga per unit yang rendah. Perusahaan dengan ukuran besar membeli bahan baku (input produksi) dalam jumlah yang besar, sehingga perusahaan akan mendapat potongan harga (quantity discount) lebih banyak daripada pemasok. Perusahaan yang lebih besar memiliki akses yang lebih besar pula untuk mendapatkan sumber pendanaan dari berbagai sumber, sehingga untuk mendapatkan pinjaman dari kreditur pun akan lebih mudah karena perusahaan dengan ukuran besar memiliki profitabilitas lebih besar untuk memenangkan persaingan atau bertahan dalam industri.

\section{Penelitian Terdahulu}

Dalam sub-bab ini akan dijabarkan penelitian yang mendukung penulisan. Penelitian terdahulu menunjukkan hasil, dan variabel yang digunakan. Hasil penelitian Fachrudin (2011) menunjukkan bahwa struktur modal berpengaruh positif dan signifikan terhadap agency cost. Ukuran perusahaan negatif terhadap agency cost. Selain itu, secara langsung struktur modal hamper berpengaruh terhadap kinerja perusahaan. Namun, secara tidak langsung struktur modal tidak berpengaruh. Ukuran perusahaan tidak berpengaruh terhadap kinerja perusahaan baik secara langsung maupun tidak langsung.

Berdasarkan hasil penelitian Hasania dkk. (2016) dibuat kesimpulan variabel current ratio $(\mathrm{CR})$ berpengaruh secara signifikan terhadap nilai perusahaan. Variabel ukuran perusahaan tidak berpengaruh signifikan terhadap nilai perusahaan. Variabel struktur modal berpengaruh secara signifikan terhadap nilai perusahaan. Variabel ROE berpengaruh secara signifikan terhadap nilai perusahaan. Secara simultan CR, ukuran perusahaan, struktur modal, dan ROE berpengaruh secara signifikan terhadap nilai perusahaan. 
Penelitian Deitiana (2011) meneliti pengaruh rasio keuangan, pertumbuhan penjualan, dan deviden terhadap harga saham. Variabel yang digunakan adalah current ratio, return on equity, dan deviden price ratio. Dari hasil pengujian, hipotesis dinyatakan bahwa profitabilitas berpengaruh terhadap harga saham, sedangkan likuiditas, deviden, dan pertumbuhan penjualan tidak berpengaruh terhadap harga saham. Penelitian Nurmalasari (2010) menunjukkan kinerja keuangan diukur menggunakan rasio keuangan, yaitu current ratio (CR), debt to equity ratio (DER), return on assets (ROA), return on equity (ROE), dan earning per share (EPS). Hasil penelitian tersebut menyimpulkan bahwa current ratio dan earning per share memiliki hubungan positif (searah). Hubungan yang positif berarti kenaikan current ratio dan earning per share akan diikuti kenaikan harga saham. Demikian pula dengan penurunan current ratio dan earning per share akan diikuti juga penurunan harga saham.

\section{Hipotesis Penelitian}

Berdasarkan tujuan dan rumusan masalah yang ada dalam penelitian ini, selanjutnya hipotesis dirumuskan sebagai berikut:

1. H1: current ratio berpengaruh terhadap kinerja keuangan perusahaan pertambangan yang terdaftar di BEI periode 2014-2016.

2. H2: struktur modal berpengaruh terhadap kinerja keuangan perusahaan pertambangan yang terdaftar di BEI periode 2014-2016.

3. H3: ukuran perusahaan berpengaruh terhadap kinerja keuangan perusahaan pertambangan yang terdaftar di BEI periode 2014-2016.

\section{METODE PENELITIAN}

Berdasarkan tujuan penelitian yang hendak dicapai, maka penelitian ini menggunakan pendekatan kuantitatif dan data sekunder berupa data annual report dan Laporan Keuangan perusahaan pertambangan yang terdaftar di BEI dan ICMD (Indonesian Capital Market Directory) tahun 2014-2016. Pendekatan kuantitatif merupakan pendekatan yang bertitik tolak dari beberapa peristiwa yang muncul dan dapat diukur secara kuantitatif atau dinyatakan dengan angka-angka. Tujuan dari penelitian kuantitatif, yaitu menguji teori, meletakkan teori yang akan menjadi landasan dalam penemuan dan pemecahan penelitian dengan menggunakan alat bantu statistik untuk melakukan pengujian, sehingga dapat menghasilkan kesimpulan (Subyantoro, 2007:78)

Penelitian ini merupakan studi empiris dalam bentuk pengujian hipotesis (hypothesis testing) yang akan menjelaskan sifat dari hubungan tertentu atau yang bisa menentukan perbedaan dua faktor independen atau lebih dalam sebuah situasi (Sekaran, 2006). Penelitian ini akan menjelaskan pengaruh struktur modal, ukuran perusahaan, dan current ratio $(\mathrm{X})$ terhadap kinerja keuangan $(\mathrm{Y})$ pada perusahaan pertambangan yang terdaftar di Bursa Efek Indonesia periode tahun 2014-2016. Penelitian ini bertujuan untuk memberikan bukti tentang pengembangan hipotesis yang telah diajukan melalui alat analisis regresi berganda serta pengolahan data yang akan dibantu dengan menggunakan program Statistical Product and Service Solution (SPSS) versi 22. 


\section{Definisi Operasional Variabel}

Sudjimat (2004:33) mengatakan bahwa definisi operasional adalah mendefinisi-kan variabel berdasarkan karakteristik yang diamati, sehingga memudahkan peneliti untuk melakukan pengukuran dan observasi dengan cermat terhadap suatu kejadian yang kemudian dapat diulangi lagi oleh yang lainnya. Berikut ini merupakan definisi operasional dari variabel-variabel yang digunakan dalam penelitian ini.

\section{Kinerja Keuangan}

Kinerja keuangan yang diukur dengan menggunakan rasio ROE (Return on Equity). ROE merupakan rasio keuangan yang dapat menunjukkan besarnya laba bersih yang diperoleh dari ekuitas yang dimiliki perusahaan, sehingga dapat diformulasi-kan sebagai berikut:

$$
\text { Return On Equity }=\frac{\text { Laba Bersih }}{\text { Total Ekuitas }}
$$

\section{Current Ratio}

Menurut Kasmir (2014:134), rasio lancar (current ratio) merupakan rasio untuk mengukur kemampuan perusahaan membayar kewajiban jangka pendek atau utang yang segera jatuh tempo pada saat ditagih secara keseluruhan. Dengan kata lain, seberapa banyak aktiva lancer yang tersedia untuk menutupi kewajiban jangka pendek yang segera jatuh tempo. Rumusan untuk mencari current ratio menurut Kasmir (2014:135) yaitu:

$$
\text { Current ratio }=\frac{\text { Aset lancar }(\text { Current Assets })}{\text { Utang Lancar }(\text { Current Liabilities })} \times 100 \%
$$

\section{Struktur Modal}

Struktur modal dalam penelitian ini menggunakan rasio leverage, yaitu DER (Debt to Equity Ratio). Hal ini menunjukkan bahwa seberapa besar perusahaan memanfaatkan pendanaannya melalui hutang yang diperoleh. Berikut perhitungannya:

$$
\text { DER : } \frac{\text { Total Liabilities }}{\text { Total Equity }}
$$

\section{Ukuran Perusahaan}

Ukuran perusahaan adalah besarnya perusahaan yang dinilai dengan menggu-nakan kriteria tertentu. Penelitian ini menggunakan kriteria total asset, yaitu:

$$
\text { Ukuran Perusahaan }=\text { LNETotalAsset }
$$




\section{Jenis dan Sumber Data}

Jenis dari sumber data yang dipakai dalam penelitian ini adalah data primer dan data sekunder.

\section{Data Primer}

Data Primer adalah data yang langsung diperoleh dari sumber asli atau informan yang memiliki informasi atau data tersebut (Idrus, 2009:86). Dalam penelitian ini, sumber data primer diambil berdasarkan konfirmasi responden yang berasal dari kuesioner yang telah dibagikan. Di dalam kuesioner yang dibagikan terdapat dua bagian, yaitu yang pertama berisi mengenai identitas responden dan yang kedua berisi pertanyaan yang berkaitan mengenai variabel bebas (independen) dan variabel terikat (dependen) pada penelitian ini yang telah dikemukakan sebelumnya.

2. Data sekunder

Data sekunder adalah data yang diperoleh dari sumber kedua atau bukan informan asli yang memiliki informasi atau data tersebut (Idrus, 2009:86). Dalam penelitian ini, sumber data sekunder diambil dari dokumen, informasi, data yang berasal dari Laporan Keuangan dan Laporan Tahunan perusahaan pertambangan yang terdaftar di BEI selama periode tahun 2014-2016.

\section{Prosedur Pengumpulan Data}

Metode pengumpulan data dalam penelitian ini adalah dengan metode studi kepustakaan dan dokumentasi, yaitu:

1. Studi Pustaka

Metode ini digunakan untuk memperoleh landasan teori yang relevan dan mendukung untuk dijadikan dalam menjawab hipotesis yang diajukan melalui literatur-literatur seperti buku, jurnal, dan penelitian terdahulu.

\section{Dokumentasi}

Metode ini digunakan untuk mengumpulkan data dengan cara mengunduh, mencatat, meneliti, dan menyalin informasi yang berkaitan dengan masalah yang dibahas dalam penelitian ini.

\section{Populasi dan Sampel}

\section{Populasi}

Populasi adalah wilayah generalisasi yang terdiri atas obyek atau subyek yang mempunyai kualitas dan karakter tertentu yang ditetapkan oleh peneliti untuk dipelajari, kemudian ditarik kesimpulannya (Anshori \& Iswati, 2009:92). Populasi penelitian ini adalah perusahaan pertambangan yang terdaftar di BEI selama kurun waktu tahun 2014-2016.

\section{Sampel}

Sampel adalah bagian atau wakil dari populasi yang diteliti. Dari populasi tersebut, pengambilan sampel ditentukan secara tidak acak atau bersifat purposive sampling. 
Purposive sampling atau sampel bertujuan merupakan teknik yang digunakan untuk penentuan sampel yang dilakukan dengan pertimbangan tertentu (Anshori \& Iswati, 2009:105). Kriteria-kriteria yang ditentukan dalam penelitian ini adalah:

1. Perusahaan pertambangan yang telah terdaftar di BEI pada tahun 2014-2016.

2. Perusahaan yang mempublikasikan annual report dan laporan keuangan secara lengkap dan berturut-turut selama tahun 2014-2016 agar variabel dapat diketahui dan dihitung.

\section{Teknik Analisis}

Untuk mendapatkan hasil sesuai dengan tujuan penelitian dan pengujian hipotesis yang diajukan, data yang diperoleh akan diolah sesuai dengan kebutuhan penelitian. Pada sub bab ini akan dijelaskan mengenai statistik diskriptif dan menjelaskan mengenai alat uji yang digunakan untuk menguji hipotesis yang telah diajukan dalam penelitian ini.

\section{Statistik Diskriptif}

Langkah awal yang harus dilakukan dalam proses pengolahan data adalah statistik diskriptif. Statistik diskriptif merupakan metode statistik yang digunakan untuk menggambarkan data yang telah dikumpulkan. Gambaran atau diskripsi tersebut dapat dinilai dari mean, standar deviasi, varian, maksimum, minimum, sum, range, kurtosis, dan skewness (Ghozali, 2013:19).

\section{Uji Asumsi Klasik}

Untuk mendapatkan model regresi yang baik dan mampu memberikan estimasi yang andal dari hasil penelitian, uji asumsi klasik yang dilakukan dalam penelitian ini adalah uji normalitas, uji multikolinieritas, uji heteroskedastisitas, dan uji autokorelasi.

\section{HASIL PENELITIAN}

\section{Diskripsi Data}

Penelitian ini menggunakan data sekunder yang diperoleh dari website resmi Bursa Efek Indonesia (BEI), yaitu www.idx.co.id., Indonesian Capital Market Directory (ICMD) tahun 2012-2015, Yahoo finance, dan sumber informasi lain yang mendukung. Data yang digunakan adalah laporan keuangan perusahaan pertambangan periode tahun 2014-2016.

Metode pengambilan sampel pada penelitian ini diambil dengan teknik purposive sampling, yaitu mendapatkan sampel yang reprensentative. Berdasarkan pengambilan sampel dengan metode tersebut, maka kriteria perusahaan yang dijadikan sebagai populasi adalah semua perusahaan property dan real estate yang terdaftar di BEI. Jumlah sampel yang digunakan untuk penelitian sebanyak 40 perusahaan pada tahun 2014-2016. Tabel 1 berikut ini adalah hasil statistik diskriptif yang berisi variabel penelitian, jumlah sampel, nilai minimum dan maksimum masing-masing variabel, nilai rata-rata dan standar deviasi variabel penelitian. 
Tabel 1. Statistik Diskriptif

\begin{tabular}{lrrrrr} 
& N & Minimum & Maximum & \multicolumn{1}{c}{ Mean } & Std. Deviation \\
\hline CURRENT RATIO & 120 & 1.99 & 11.66 & 4.6288 & 1.56013 \\
STRUKTUR MODAL & 120 & -1.70 & 1.38 & -.0931 & .49136 \\
UKURAN PERUSAHAAN & 120 & 5.22 & 7.94 & 6.7069 & .62174 \\
KINERJA KEUANGAN & 120 & -3.40 & 4.61 & 1.7378 & 1.41114 \\
\hline Valid N (listwise) & 120 & & & &
\end{tabular}

Sumber: Data sekunder yang diolah, 2018.

Berdasarkan hasil perhitungan uji statistik deskriptif pada Tabel 1 menjelaskan bahwa dari 120 perusahaan sampel selama periode pengamatan 2014-2016, variabel Current Ratio nilai rata-rata (mean) sebesar 4,63, nilai minimum sebesar 1,99 yang terdapat pada perusahaan dalam penelitian. Variabel struktur dilihat pada rasio Debt to Equity Ratio (DER) mempunyai nilai rata-rata (mean) sebesar -0,09, untuk nilai minimum sebesar -1,70 dimiliki oleh PT Berau Coal Energy, Tbk. pada tahun 2016 dan nilai maksimum sebesar 6,71\% oleh PT Berau Coal Energy, Tbk. pula pada tahun 2015.

Variabel ukuran perusahaan dilihat pada total asset yang dimiliki mempunyai nilai rata-rata (mean) sebesar 7.4, untuk nilai minimum sebesar 5,22 dimiliki PT Perdana Karya Perkasa, Tbk. pada tahun 2016 dan nilai maksimum sebesar 7,94 juta oleh PT Adaro Energy, Tbk. tahun 2016. Variabel kinerja keuangan diukur dari ROE (Return on Equity) perusahaan sampel mempunyai nilai rata-rata (mean) sebesar 4,61, untuk nilai minimum sebesar -3,40 oleh PT Berau Coal Energy, Tbk. pada tahun 2015 dan nilai maksimum sebesar 4,61 dimiliki oleh PT Berau Coal Energy, Tbk. pada tahun 2016.

\section{Hasil Uji Asumsi Klasik}

Uji asumsi klasik dilakukan terlebih dahulu sebelum melakukan uji regresi untuk memperoleh keyakinan penggunaan model regresi menghasilkan estimator linear yang tidak bias. Pengujian asumsi klasik dalam penelitian ini dijelaskan berikut ini.

\subsection{Uji Normalitas}

Menurut Ghozali (2013), uji normalitas data dilakukan dengan tujuan untuk mengetahui apakah sampel yang diambil telah terdistribusi normal atau tidak. Suatu model regresi yang baik adalah data yang berdistribusi normal atau mendekati normal. Pengujian normalitas data dilakukan dengan menggunakan analisis grafik dengan melihat normal probability plot yang membandingkan distribusi kumulatif dari distribusi normal dan analisis statistik dengan menggunakan uji One-Sample Kolmogorov-Smirnov (K-S).

Hipotesis pengujiannya adalah jika nilai Asymp. Sig.>0,05 maka hipotesis diterima dan data terdistribusi normal. Berdasarkan hasil pengujian normal uji statistik parametrik Kolmogorov-Smirnov dengan hasil signifikansi sebesar 0,101 di atas 0,05 maka data residual terdistribusi normal (Tabel 2). 
Tabel 2. Hasil Uji Normalitas Analisis One-Sample Kolmogorov-Smirnov

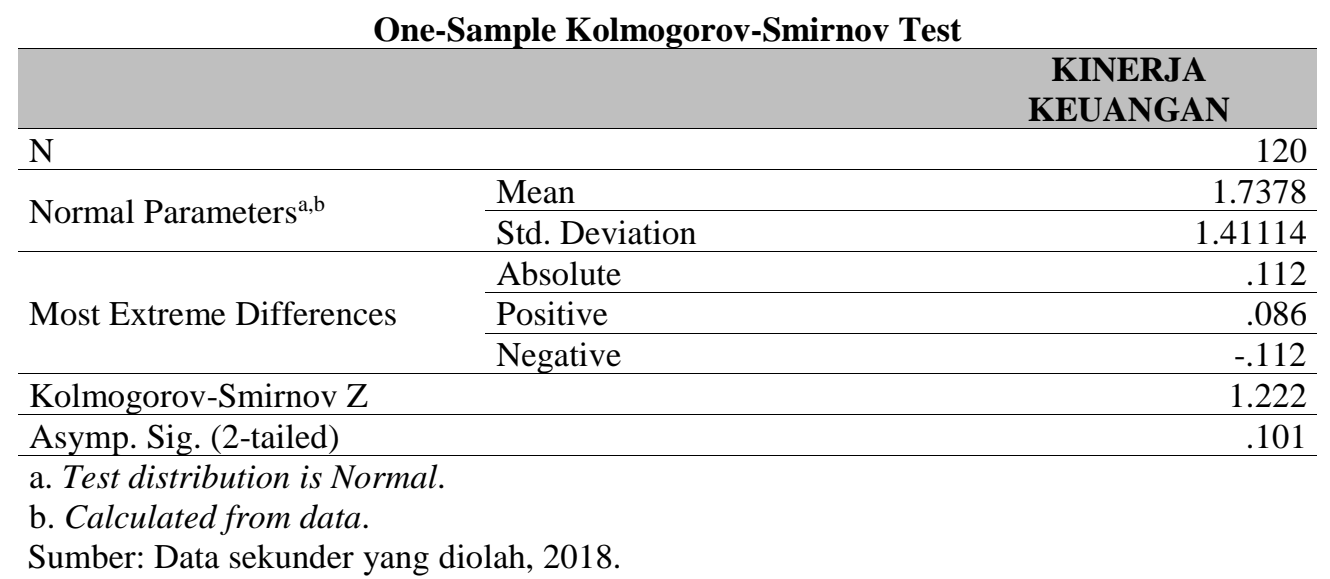

\subsection{Uji Multikolinearitas}

Uji multikolinearitas bertujuan untuk menguji apakah model regresi ditemukan adanya kolerasi antarvariabel bebas (Ghozali, 2013). Uji ini dilakukan dengan melihat nilai Variance Inflation Factor (VIF). Apabila nilai VIF di atas 10 dan nilai tolerance di bawah 0,1 maka hasil tersebut menunjukkan adanya multikoliniearitas. Sebaliknya, jika nilai VIF di bawah 10 dan nilai tolerance di atas 0,1 maka hasil tersebut menunjukkan tidak terjadi multikoliniearitas. Perhitungan uji multikolinieritas dengan bantuan program SPSS v.21 menunjukkan nilai tolerance semua variabel di atas 0,1 dan nilai VIF di bawah 10, maka dapat disimpulkan bahwa tidak terdapat multikoliniearitas antarvariabel bebas (Tabel 3).

Tabel 3. Hasil Uji Multikolinieritas

\begin{tabular}{|c|c|c|c|}
\hline \multirow[t]{2}{*}{ Model } & & \multicolumn{2}{|c|}{ Collinearity Statistic } \\
\hline & & Tolerance & VIF \\
\hline \multirow{4}{*}{1} & $($ Constant $)$ & & \\
\hline & KINERJA LINGKUNGAN & .970 & 1.031 \\
\hline & STRUKTUR MODAL & .856 & 1.168 \\
\hline & UKURAN PERUSAHAAN & .872 & 1.147 \\
\hline
\end{tabular}

a. Dependent Variable: KINERJA KEUANGAN

Sumber: Data sekunder yang diolah, 2018.

\subsection{Uji Autokorelasi}

Uji autokolerasi bertujuan untuk menguji apakah dalam suatu model regresi linear ada kolerasi antara kesalahan pada periode t dengan periode t-1 (sebelumnya). Jika terjadi korelasi, maka hal itu dinamakan adanya masalah autokolerasi (Ghozali, 2013). Pada penelitian ini, pengujian autokorelasi dilakukan dengan uji Durbin-Watson ( $D W$ test) yaitu membandingkan nilai tabel Durbin-Watson dengan nilai Durbin-Watson yang diperoleh dari perhitungan regresi, nilai Durbin-Watson dari SPSS kemudian dibandingkan dengan nilai tabel dengan tingkat signifikansi 0,05 , jumlah sampel (N) 120, dan jumlah variabel independen sebanyak 4. Apabila nilai Durbin-Watson lebih 
tinggi dari batas atas (du) dan kurang dari 4-du, maka tidak terjadi autokolerasi. Hasil pengujian dapat dilihat pada tabel berikut ini:

Berdasarkan pengujian autokorelasi dengan uji Durbin-Watson dalam penelitian ini menunjukkan bahwa tidak terjadi autokolerasi yang positif maupun negatif, sehingga persamaan regresi berganda layak digunakan untuk menguji hipotesis. Hal ini ditunjukkan dengan nilai Durbin-Watson (d) sebesar 1,6339> nilai du sebesar 1,7278 dan nilai Durbin-Watson (d) sebesar 1,820 nilai 4-du, yaitu 2,125 dan 2,2722 (Tabel 4).

Tabel 4. Hasil Uji Autokorelasi

\begin{tabular}{lccccc}
\multicolumn{5}{c}{ Model Summary $^{\mathbf{b}}$} \\
\hline Model & R & R Square & $\begin{array}{c}\text { Adjusted R } \\
\text { Square }\end{array}$ & $\begin{array}{l}\text { Std. Error of } \\
\text { the Estimate }\end{array}$ & $\begin{array}{c}\text { Durbin- } \\
\text { Watson }\end{array}$ \\
\hline 1 & & .108 & .085 & 1.34958 & 1.820 \\
\hline a. Predictors: (Constant), UKURAN PERUSAHAAN, CURRENT RATIO, STRUKTUR MODAL \\
b. Dependent Variable: KINERJA KEUANGAN
\end{tabular}

Sumber: Data sekunder yang diolah, 2018.

\subsection{Uji Heteroskedatisitas}

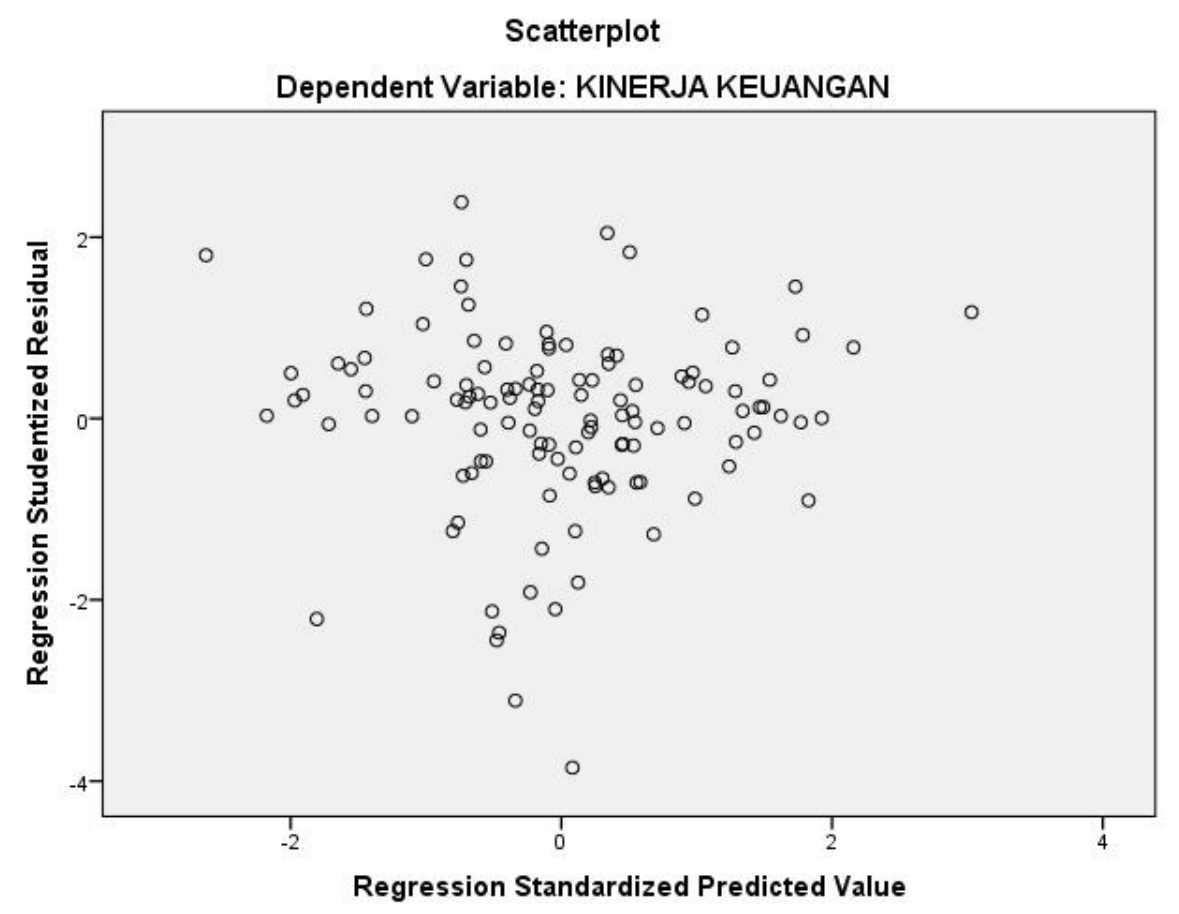

Sumber: Data sekunder yang diolah, 2018.

\section{Gambar 1. Hasil Uji Heteroskedastisitas dengan Grafik Scatterplot}

Ghozali (2013) menyatakan bahwa uji heteroskedastisitas bertujuan untuk menguji apakah dalam model regresi berganda terjadi ketidaksamaan variance dari residual suatu pengamatan ke pengamatan yang lain. Untuk mendeteksi ada tidaknya heterokedastisitas dalam penelitian ini dapat dilakukan dengan melihat grafik Scatter-plot antara SRESID dan ZPRED, yang mana sumbu Y adalah Y yang diprediksi dan sumbu 
$\mathrm{X}$ adalah residual. Jika ada pola tertentu, seperti titik-titik yang ada membentuk pola tertentu yang teratur (bergelombang, melebar kemudian menyempit), maka dapat mengindikasikan telah terjadi heterokedaktisitas.

Jika tidak ada pola yang teratur dan titik menyebar di atas dan di bawah angka 0 maka tidak terjadi heterokedastisitas. Gambar 1 berikut ini menunjukkan hasil pengujian heteroskedastisitas. Gambar 1 menunjukkan bahwa model dalam penelitian ini tidak terjadi heteroskedastisitas, karena tidak ada pola yang jelas, serta titik-titik menyebar di atas dan di bawah angka 0 pada sumbu Y. Hal ini berarti bahwa model persamaan regresi berganda yang digunakan dalam penelitian ini layak digunakan untuk menguji hipotesis.

\section{Pengujian Hipotesis dan Pembahasan}

Penelitian ini bertujuan untuk mengetahui pengaruh Current Ratio, struktur modal, dan ukuran perusahaan terhadap kinerja keuangan selama periode 2014-2016. Untuk mengetahui pengaruh tersebut, maka dilakukan pengujian terhadap hipotesis dengan metode regresi berganda yang dikembangkan oleh penulis. Keandalan dan ketepatan fungsi regresi berganda dalam menaksir nilai aktual dapat diukur dari Goodness of Fitnya. Pada perhitungan statistik, hal itu dapat diukur dari koefisien determinasi, nilai statistik t, dan nilai statistik F (Ghozali, 2013). Berikut ini merupakan penjelasan hasil pengujian hipotesis dengan persamaan regresi berganda.

\subsection{Uji Koefisien Determinasi $\left(\mathbf{R}^{2}\right)$}

Koefisien determinasi $\left(\mathrm{R}^{2}\right)$ mengukur seberapa jauh kemampuan model dalam menerangkan variasi variabel dependen. Nilai koefisien determinasi $\left(\mathrm{R}^{2}\right)$ adalah antara 0 sampai dengan 1 . Nilai koefisien determinasi $\left(\mathrm{R}^{2}\right)$ yang semakin besar atau mendekati 1 berarti variabel-variabel independen memberikan hampir semua informasi yang dibutuhkan untuk memprediksi variasi variabel dependen (Ghozali, 2013). Apabila dalam suatu model menggunakan lebih dari dua variabel independen, maka banyak peneliti menganjurkan untuk menggunakan nilai Adjusted $-\mathrm{R}^{2}$ pada saat mengevaluasi mana model regresi yang terbaik. Berdasarkan perhitungan dengan menggunakan bantuan program SPSS v.21 diketahui hasil uji $R^{2}$. Hasil perhitungan menunjukkan bahwa nilai koefisien determinasi $\left(\mathrm{R}^{2}\right)$ yaitu sebesar 0,108 (Tabel 4$)$. Hal ini berarti sebesar 10,8\% variabel dependen (Kinerja Keuangan) dijelaskan oleh variabel independen (Kinerja Lingkungan, Struktur Modal, dan Ukuran Perusahaan), sedangkan sisanya sebesar $89,8 \%$ dijelaskan oleh variabel lain atau faktor-faktor lain yang tidak dimasukkan dalam penelitian ini.

\subsection{Uji Signifikansi Parameter Parsial (Uji-t)}

Uji t dilakukan untuk menguji pengaruh variabel independen secara parsial terhadap variabel dependen, yaitu pengaruh dari masing-masing variabel independen yang terdiri dari earning per share, debt to equity ratio, price to book value, dan financial leverage terhadap harga saham sebagai variabel dependen yang dapat diketahui dari besarnya $p$-value. Apabila $p$-value lebih kecil dari tingkat signifikansinya, maka variabel independen tersebut secara parsial berpengaruh signifikan terhadap variabel dependen. Sebaliknya, apabila nilai $p$-value lebih besar dari tingkat signifikansinya, maka variabel independen tersebut secara parsial tidak berpengaruh signifikan terhadap variabel dependen. 
Tabel 5. Hasil Uji Statistik t

Coefficients $^{\mathrm{a}}$

\begin{tabular}{|c|c|c|c|c|c|c|}
\hline & \multirow[t]{2}{*}{ Model } & \multicolumn{2}{|c|}{ Unstandardized Coefficients } & \multirow{2}{*}{$\begin{array}{c}\begin{array}{c}\text { Standardized } \\
\text { Coefficients }\end{array} \\
\text { Beta }\end{array}$} & \multirow[t]{2}{*}{$\mathbf{t}$} & \multirow[t]{2}{*}{ Sig. } \\
\hline & & B & Std. Error & & & \\
\hline \multirow{4}{*}{1} & $($ Constant $)$ & 3.135 & 1.506 & & 2.082 & .040 \\
\hline & CURRENT RATIO (CR) & .142 & .081 & .157 & 1.758 & .081 \\
\hline & STRUKTUR MODAL (SM) & .959 & .272 & .334 & 3.522 & .001 \\
\hline & UKURAN PERUSAHAAN (UP) & -.293 & .213 & -.129 & -1.374 & .172 \\
\hline
\end{tabular}

a. Dependent Variable: KINERJA KEUANGAN (KK)

Sumber: Data yang diolah, 2018.

Berdasarkan Tabel 5, model persamaan regresi dalam penelitian ini mengacu pada unstandardized coefficients yang dapat dirumuskan sebagai berikut:

$$
\mathrm{KK}=3,135+0,142 \mathrm{CR}+0,959 \mathrm{SM}-0,293 \mathrm{UP}+\mathrm{e}
$$

Keterangan:

KK = Kinerja Keuangan

$\mathrm{CR}=$ Current Ratio

$\mathrm{SM}=$ Struktur Modal

UP = Ukuran Perusahaan

e $\quad=$ Koefisien Error

Hasil persamaan regresi berganda tersebut, pada masing-masing variabel dapat diinterpretasikan pengaruhnya terhadap Kinerja Keuangan perusahaan sebagai berikut:

a. Konstanta sebesar 3,135 artinya jika variabel Current Ratio, Struktur Modal, dan Ukuran Perusahaan dianggap tidak ada perubahan atau konstan, maka Kinerja Keuangan perusahaan telah memiliki nilai sebesar 3,135.

b. Current Ratio memiliki koefisien positif sebesar 0,142. Hal ini berarti bahwa Curent Ratio mempunyai hubungan yang searah dengan Kinerja Keuangan perusahaan atau setiap perubahan CR bertambah $1 \%$, maka akan meningkatkan Kinerja Keuangan sebesar 0,142 jika variabel independen lain dianggap tetap.

c. Struktur Modal memiliki koefisien positif sebesar 0,959. Hal ini berarti bahwa Struktur Modal mempunyai hubungan yang searah dengan Kinerja Keuangan atau setiap perubahan Struktur Modal bertambah 1\%, maka akan meningkatkan Kinerja Keuangan sebesar 0,959 jika variabel independen lain dianggap tetap.

d. Ukuran Perusahaan memiliki koefisien negatif sebesar-0,293. Hal ini berarti bahwa Ukuran Perusahaan mempunyai hubungan yang berlawanan dengan Kinerja Keuangan atau setiap perubahan ukuran perusahaan bertambah $1 \%$ maka akan menurunkan Kinerja Keuangan sebesar -0,293 jika variable independen lain dianggap tetap.

\subsection{Pengujian Hipotesis}

a. Pengujian Hipotesis 1 
H1: Current Ratio berpengaruh terhadap kinerja keuangan perusahaan pertambangan yang terdaftar di BEI periode 2014-2016.

Hasil perhitungan uji t di atas terlihat bahwa nilai t-hitung variabel Current Ratio sebesar 1,506 dengan nilai signifikansi (Sig. t) sebesar 0,081. Data tersebut menunjukkan bahwa Sig t $0,081>0,05$ maka $\mathrm{H}_{1}$ ditolak. Artinya, variabel Current Ratio tidak berpengaruh terhadap kinerja keuangan perusahaan pertambangan.

Hasil penelitian ini tidak sesuai dengan penelitian Prateenkant (2011) yang menunjukkan bahwa terdapat hubungan negatif antara current ratio terhadap kinerja keuangan. Kinerja keuangan dalam hal ini menggunakan rasio debt to equity (DER).

b. Pengujian Hipotesis 2

H2: Struktur modal berpengaruh terhadap kinerja keuangan perusahaan pertambangan yang terdaftar di BEI periode 2014-2016.

Hasil perhitungan uji t di atas diketahui bahwa nilai t-hitung variabel struktur modal sebesar 3,522 dengan nilai signifikansi (Sig. t) sebesar 0,001. Dari data tersebut menunjukkan bahwa Sig. 0,001<0,05 maka $\mathrm{H}_{2}$ diterima. Artinya, variabel struktur modal berpengaruh terhadap kinerja keuangan perusahaan.

Hasil penelitian ini sesuai dengan Fachrudin (2011) yang menyebutkan bahwa secara parsial variabel struktur modal berpengaruh positif dan signifikan terhadap agency cost, sehingga semakin tinggi nilai struktur modal, maka semakin tinggi nilai kinerja keuangan perusahaan.

c. Pengujian Hipotesis 3

H3: Ukuran perusahaan berpengaruh terhadap kinerja keuangan perusahaan pertambangan yang terdaftar di BEI periode 2014-2016.

Hasil perhitungan uji $\mathrm{t}$ di atas diketahui bahwa nilai t-hitung variabel ukuran perusahaan sebesar -1,374 dengan nilai signifikansi (Sig. t) sebesar 0,172. Dari data tersebut menunjukkan bahwa Sig. t 0,172>0,05 maka $\mathrm{H}_{3}$ ditolak. Artinya, variabel ukuran perusahaan tidak berpengaruh terhadap kinerja keuangan perusahaan pertambangan.

Hasil ini sesuai dengan Agrestya (2011) yang menyatakan bahwa ukuran perusahaan berpengaruh negatif dan signifikan terhadap kinerja keuangan yang diproksikan dengan ROA dan struktur modal yang diproksikan dengan DER berpengaruh negatif dan signifikan terhadap kinerja keuangan yang diproksikan dengan ROA.

\subsection{Uji Signifikan Parameter Simultan (Uji F)}

Uji statistik $F$ atau uji signifikansi simultan menunjukkan apakah semua variabel independen yang dimasukkan dalam model, secara bersama-sama mempunyai pengaruh terhadap variabel dependen (Ghozali, 2013). Jadi, uji F dapat mengetahui apakah variabel berpengaruh secara signifikan terhadap harga saham perusahaan. Berdasarkan perhitungan dengan menggunakan bantuan program SPSS v.21 diketahui hasil uji $\mathrm{F}$ ditunjukkan dengan nilai $\mathrm{F}$ sebesar 4,701 dan angka probabilitas signifikansi $0,004<$ tingkat signifikansi 0,05 (Tabel 6). Hasil ini menunjukkan bahwa variabel independen yang terdiri atas current ratio, struktur modal, dan ukuran perusahaan secara bersamasama mempunyai pengaruh terhadap variabel dependen, yaitu Kinerja Keuangan (Y) pada perusahaan pertambangan pada periode tahun 2014-2016. 
Tabel 6. Hasil Uji Statistik F

\begin{tabular}{rlrrrrr}
\multicolumn{8}{c}{ ANOVA $^{\text {a }}$} \\
\hline & Model & Sum of Squares & df & Mean Square & \multicolumn{1}{c}{ F } & Sig. \\
\hline \multirow{3}{*}{1} & Regression & 24.218 & 3 & 8.073 & 4.701 & $.004^{\text {b }}$ \\
& Residual & 212.747 & 116 & 1.834 & & \\
& Total & 236.965 & 119 & & & \\
\hline
\end{tabular}

a. Dependent Variable: KINERJA KEUANGAN

b. Predictors: (Constant), CURRENT RATIO, STRUKTUR MODAL, UKURAN PERUSAHAAN

Sumber: Data sekunder yang diolah, 2018.

\section{KESIMPULAN DAN SARAN}

Berdasarkan hasil penelitian yang dilakukan untuk menguji pengaruh Current Ratio, Struktur Modal, dan Ukuran Perusahaan terhadap Kinerja Keuangan pada perusahaan di sektor pertambangan yang terdaftar di Bursa Efek Indonesia (BEI) periode tahun 2014-2016 dengan total sampel 120 laporan keuangan, maka dapat diambil beberapa kesimpulan bahwa data yang digunakan dalam penelitian ini terdistribusi normal, tidak terdapat multikolinieritas, bebas autokorelasi dan tidak terjadi heteroskedastisitas, sehingga persamaan regresi yang digunakan adalah tepat. Ada pun hasil analisis data dapat disimpulkan sebagai berikut:

1. Current ratio tidak berpengaruh signifikan terhadap kinerja keuangan pada perusahaan pertambangan di Bursa Efek Indonesia (BEI) pada tahun 2014-2016.

2. Struktur modal berpengaruh signifikan terhadap kinerja keuangan perusahaan pertambangan di Bursa Efek Indonesia (BEI) pada tahun 2014-2016.

3. Ukuran perusahaan tidak berpengaruh terhadap kinerja keuangan perusahaan pertambangan di Bursa Efek Indonesia (BEI) pada tahun 2014-2016.

Berdasarkan kesimpulan dari penelitian ini, maka peneliti memberikan beberapa saran yang dapat diajukan sebagai berikut:

1. Bagi peneliti selanjutnya perlu memilih perusahaan di bidang lain untuk memperoleh hasil penelitian yang lebih memiliki daya generalisasi guna mempertinggi daya uji empiris tentang pengaruh Current ratio, Struktur Modal, dan Ukuran Perusahaan terhadap Kinerja Keuangan pada perusahaan.

2. Bagi peneliti selanjutnya sebaiknya menambahkan variabel independen yang masih berbasis pada data laporan keuangan selain yang digunakan dalam penelitian ini.

3. Bagi peneliti selanjutnya perlu menambah periode pengamatan penelitian, karena semakin lama interval waktu pengamatan, maka semakin besar pula kesempatan untuk memperoleh informasi mengenai variabel yang memperoleh hasil penelitian yang lebih akurat.

4. Implikasi hasil penelitian ini bermanfaat bagi investor sebagai bahan pertimbangan dalam pengambilan keputusan investasi. 


\section{DAFTAR REFERENSI}

Al-Tuwaijri, S. A., Christensen, T. E., \& Hughes, K. (2004). The relations among environmental disclosure, environmental performance, and economic perform-ance: a simultaneous equations approach. Accounting, organizations and society, 29(5), 447471.

Angela, \& Yudianti, F. N. (2015). Pengaruh Kinerja Lingkungan terhadap Kinerja Finansial dengan Pengungkapan Corporate Social Responsibility (CSR) sebagai Variabel Intervening. Simposium Nasional Akuntansi 18, Medan.

Badan Pusat Statistik (2015). Distribusi Produk Domestik Bruto Seri 2010 Triwulanan Atas Dasar Harga Berlaku Menurut Lapangan Usaha (Persen), 2010- 2014. Jakarta: BPS. Tersedia pada: http://www.bps.go.id.

Bastian, I. (2006). Akuntansi Sektor Publik: Suatu Pengantar. Jakarta: Erlangga.

Brealey, R. A., et al. (2011). Dasar-Dasar Manajemen Keuangan Perusahaan. Jilid 2, Terjemahan oleh Bob Sabran. Jakarta: Erlangga.

Budimanta, A., Prasetyo, A. \& Rudito, B. (2008). Corporate Social Responsibility: Alternatif bagi Pembangunan Indonesia. Jakarta: ICSD.

Bursa Efek Indonesia (2014). Laporan IDX LQ45. Jakarta: BEI. Tersedia pada: http://www.idxco.id/ id-id/beranda/publikasi/lq45.aspx.

Bursa Efek Indonesia (2014). Laporan Keuangan dan Tahunan. Jakarta: BEI. Tersedia pada: http://www.idx.co.id.

Fachrudin, K. A. (2011). Analisis Pengaruh Struktur Modal, Ukuran Perusahaan, dan Agency Cost Terhadap Kinerja Perusahaan. Jurnal Akuntansi dan Keuangan, 13(1), 37-46.

Fahmi, I. (2011). Analisis Laporan Keuangan. Bandung: Alfabeta.

Ghozali, I. (2013). Aplikasi Analisis Multivariate dengan Program SPSS. Edisi Ketujuh. Semarang: Badan Penerbit Universitas Diponegoro

Hadi, N. (2011). Corporate Social Responsibility. Yogyakarta: Graha Ilmu.

Kasmir (2014). Pengantar Manajemen Keuangan. Jakarta: Kencana.

Maiyarni, R., Susfayetti, \& Erwati, M. (2014). Pengaruh Profitabilitas, Ukuran Perusahaan, Likuiditas, dan Leverage Terhadap Pengungkapan Corporate Social Responsibility (CSR) pada Perusahaan LQ-45 yang Terdaftar di Bursa Efek Indonesia Periode 20092012. Jurnal Cakrawala Akuntansi ISSN 1979-4851 Vol. 6 No. 1, Februari 2014, hal. 79-94.

Munawir (2000). Analisis Laporan Keuangan. Yogyakarta: Liberty.

Niresh, J. A., \& Velnampy, T. (2014). Firm Size and Profitability: A Study of Listed Manufacturing Firms in Sri Lanka. Sri Lanka: University of Jaffna.

Wild, J. J. (2005). Analisis Laporan Keuangan. Buku Satu. Edisi Delapan. Jakarta: Salemba Empat.

Yanti, N. K. A. G. \& Budiasih, I. G. A. N. (2016). Pengaruh Profitabilitas, Leverage dan Ukuran Perusahaan pada Pengungkapan Corporate Social Responsibility. E-Jurnal Akuntansi Universitas Udayana, Vol. 17/3 Desember. ISSN: 2302-8556 p.1752-1779.

Zani, J., Leites, E. T., Macagnan, C.B., \& Portal, M. T. (2013). Interest on Equity and Capital Structure in the Brazilian Context. International Journal of Managerial Finance, Vol. 10 No.1, pp. 39-53. 